\title{
Akut lenfadenit ile gelen bir kedi tırmığı olgusu
}

\author{
A case of cat scratch disease with acute lymphadenitis
}

Gürbüz Akçay, Hatice Topal

Özet: Kedi tırmığı hastalığı Bartonella henselae'nin neden olduğu enfeksiyöz bir hastalıktır. Daha çok yavru kedilerden geçmektedir. İmmun sistemi zayıf olan kişilerde sistemik hastalık yapabilmesine karşın çoğu zaman lokal enfeksiyon ve ağrılı lenfadenitle seyretmektedir. Günümüzde tanıda seroloji ve PCR büyük kolaylık sağlamaktadır. Bu hastalık bilinenden daha fazla olabilir. Akla gelmesi tanı ve tedavide kolaylık sağlayacaktır. Ağrılı lenfadeniti olan, amoksisiline yanıt vermeyince yapılan serolojik testte Bartonella henselae antikorlarını tespit ederek tanısını koyduğumuz ve spesifik tedaviye yanıt veren 10 yaşındaki çocuk vakayı sunduk.

Anahtar kelimeler: Kedi tırmığı hastalığı, azitromisin, lenfadenit.

Akçay G, Topal H. Akut lenfadenit ile gelen bir kedi tırmığı olgusu. Pam Tıp Derg 2020;13:823-826.

\begin{abstract}
Cat-scratch disease is an infectious disease caused by Bartonella henselae. It mostly passes through kittens. It can cause systemic disease in people with a weak immune system, while it usually progresses with local infection and painful lymphadenitis. Today, serology and PCR provide great convenience in diagnosis. This disease may be seen more frequently than known. Keeping that in mind will facilitate diagnosis and treatment. We reported a 10-year-old child case with painful lymphadenitis, which we detected by diagnosing Bartonella henselae antibodies in a serological test that did not respond to amoxicillin and responded to the specific treatment.
\end{abstract}

Key words: Cat-scratch disease, azithromycin, iymphadenitis.

Akcay G, Topal H. A case of cat scratch disease with acute lymphadenitis. Pam Med J 2020;13:823-826.

\section{Giriş}

Kedi tırmığı hastalığı (KTH), kedi tırmığı ateşi ya da subakut rejyonal lenfadenit olarak da bilinen, Bartonella henselae (B.henselae) isimli bakterinin yapmış olduğu bir enfeksiyöz hastalıktır [1]. Çocuklarda daha sık görülmekte ve genellikle tırmalanan bölgedeki lenf bezlerindeki inflamasyonla sınırlı kalmaktadır. Nadir de olsa, granulomatöz konjunktivit, atipik pnömoni, trombositopeni ve ensefalite de neden olabilmektedir [2-4]. Rutin antibiyotik tedavisine yanit vermeyen akut lenfadenit ya da nedeni bilinmeyen sistemik ateşlerde KTH açısından özgeçmiş sorgulaması ve serolojik test yapılması tanıyı koymada kolaylık sağlamaktadır. Lenfadenit ayırıcı tanısında kedi tırmığı hastalığının da ayırıcı tanıda düşünülmesi gerektiğini vurgulamak amacıyla bu olgu sunulmuştur.

\section{Olgu sunumu}

On yaşında kız hasta sağ dirsek, sağ koltukaltı ve sağ klavikular bölgede ağrı şikâyeti ile getirildi. Yaklaşık 20 gün önce sağ kolda başlayan ağrı, ardından 2 gün sonra aynı taraf dirsek kısmında şişlik ve ateş yakınmalarının ortaya çıktığı öğrenildi. Üç gün önce başvurduğu sağlık kuruluşunda, amoksisilin-klavulanik asit ve metronidazol tedavisinin başlandığı, ancak hastanın şikayetlerinin geçmemesi üzerine kliniğimize başvurduğu öğrenildi. Önceki başvurusunda yapılan tetkiklerinden ultrasonografide (USG) nonspesifik bulgular olması üzerine, maligniteden ayırt etmek için magnetik rezonans görüntüleme çekildiği, medial epitroklear nekrotik lezyon ve sağ aksiler lenfadenopati mevcudiyeti şeklinde raporlandığı bildirildi. Ateşin genellikle akşamüstü aniden yükseldiği, $38,2^{\circ} C^{\prime}$ ye kadar

Gürbüz Akçay, Dr. Öğr. Üye. Pamukkale Üniversitesi Tıp Fakültesi Çocuk Sağlığı ve Hastalıkları Anabilim Dalı, Denizli, Türkiye, e-posta: gurbuzakcay@ hotmail.com (orcid.org/0000-0002-4682-9258) (Sorumlu Yazar)

Hatice Topal, Dr. Öğr. Üye. Muğla Sıtkı Koçman Üniversitesi Tıp Fakültesi Çocuk Sağlığı ve Hastalıkları Anabilim Dalı, Muğla, Türkiye, e-posta: haticetopaldr@gmail.com (orcid.org/000-0002-7059-4823) 
çıktığı, gündüzleri daha düşük olduğu ifade edildi. Hastanın iştahının azaldığı, dışkılama ve idrarla ilgili şikâyetlerinin olmadığı öğrenildi. Özgeçmişinde özellik yoktu. Aile öyküsünde annede hipertansiyon, babada böbrek taşı ve hipertansiyon, 2 ablasından birinde hashimato tiroiditi olduğu belirtildi.

Fizik muayenesinde Ağırlık 50 kg (\%94,74), boy $157,5 \mathrm{~cm}(\% 98,87)$, VKI $20,16 \mathrm{~kg} / \mathrm{m} 2$ (\%80,51), Kan basıncı: 100/60mmHg, Kalp tepe atımı 90/dak, vücut sıcaklığı $36,5^{\circ} \mathrm{C}$ ölçüldü. Genel durumu iyi ve koopere idi. Ciltte karın her iki para umblikal bölgede terra firma forme dermatozu (TFFD) ve sol skapular bölgede 2 $\mathrm{cm}$ nevüs izlendi. Sağ kol dirsek bölgesinde 5x5 cm cilt altı ağrılı yumuşak kitle (Resim 1), sağ klavikular bölgede $5 \times 5 \mathrm{~cm}$ ağrılı, yumuşak cilt altı kitle (Resim 2) ele geliyordu ve sağ aksiller bölgede hassasiyet vardı. Diğer sistemik muayene bulguları normal olarak değerlendirildi.

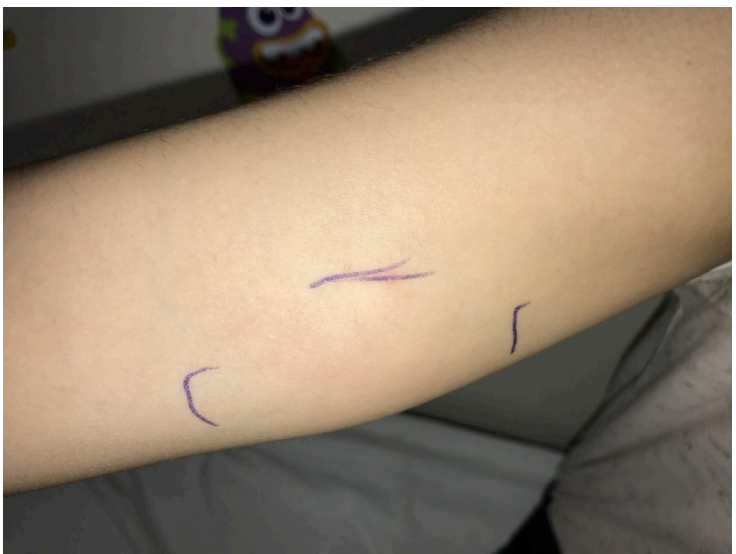

Resim 1. Medial epitroklear lenfadenopati; Tedavi öncesi. Ağrılı, 5x5 cm ebadında

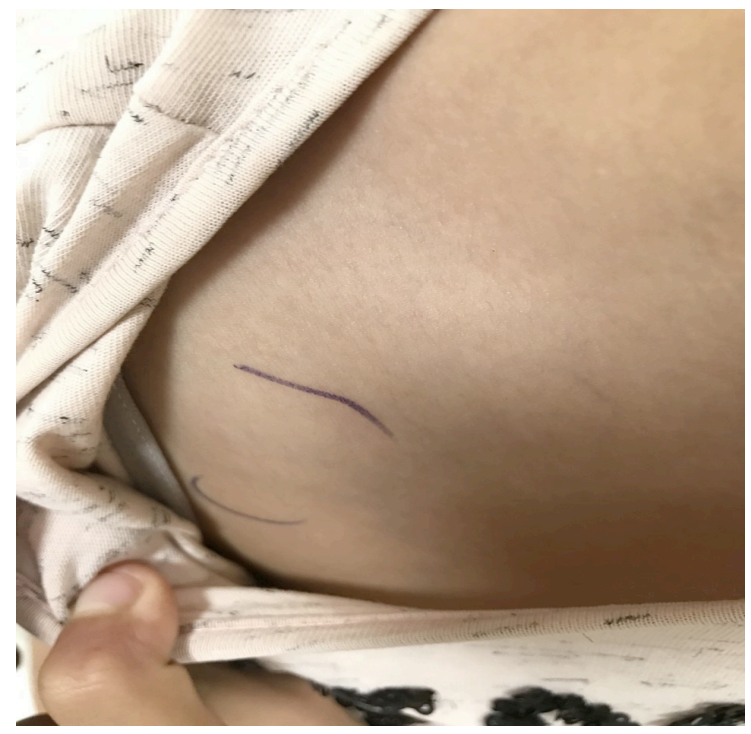

Resim 2. Sağ klavikula önünde cilt altı kitle
Hastanın öyküsü yeniden sorgulandığında bahçede ve içeride sürekli kedi bulunduğu ve hastamızın da kedilerle devamlı oynadığı öğrenildi. Hastanın yakınma, öykü ve fizik muayenesi sonrası kedi tırmığı hastalığı olabileceği düşünüldü. Göz tutulumunu dışlamak için göz konsültasyonu istendi, göz basıncı, görme keskinliği, biomikroskobisi, fundus-optik disk muayeneleri ve OCT ölçümü normal olarak değerlendirildi. Akciğer grafisi normaldi. Batın içi tutulum açısından çekilen tüm batın USG'de her iki overde çok sayıda ufak milimetrik nonfonksiyonel foliküller dışında anormal bulgu saptanmadı. CRP $1,233 \mathrm{mg} /$ $\mathrm{dL}(\mathrm{n}:<0,5)$ ve eritrosit sedimantasyon hız 47 $\mathrm{mm} / \mathrm{saa}$ ölçüldü, diğer hemogram ve rutin biyokimya testleri normal olarak tespit edildi. Brucella rose bengal ve aglütinasyon testi negatif çıktı. Kedi Tırmığı hastalığı açısından Bartonella Henselae'ye yönelik seroloji testi istendi. Hastada B.henselae IgM 1/100 pozitif, B.henselae lgG 1/320 pozitif idi. Anamnez ve lezyonun lokalizasyonu nedeniyle ön planda $\mathrm{KTH}$ düşünüldüğü için ve serolojik testlerin de bu açıdan pozitif çıkması nedeniyle CMV ve Toksoplasma enfeksiyonlarına yönelik testleri istenmedi.

Hastamıza kedi tırmığı hastalığı tanısıyla klaritromisin $15 \mathrm{mg} / \mathrm{kg} / \mathrm{gün}$ ve trimetoprimsulfametoksazol $8 \mathrm{mg} / \mathrm{kg} / \mathrm{gün}$ tedavisi başlandı ve 15 güne tamamlandı. Tedavi sonrası kontrollerinde ağrılarının tamamen gerilediği ancak lenfadenopatinin boyutlarında küçülme olmakla birlikte sebat ettiğinin tespit edilmesi üzerine azitromisin 1x500 mg dozunda beş gün süreyle verildi. Tedavi sonrası 50. gün kontrole geldiğinde sağ dirsekteki kitlenin boyu $5 \times 5$ cm'den 3x1 cm'ye gerilediği, iştahının düzeldiği ve 2 kg tartı alımı olduğu görüldü.

\section{Tartışma}

Bartonella henselae gram negatif çomak şeklinde, intraselüler yaşayan bakteridir. Hastalarda genellikle bir kedi, özellikle de kedi yavrusu, tırmalama hikâyesi vardır. Bakteri insana tırmalama ya da ısırma yoluyla geçmektedir. Evcil kediler başlıca rezervuardır. Bakteri kediler arasında pire ile aktarılmaktadır [5]. Bölgemizde kedilerde yapılan bir çalışmada Bartonella taşıyıcılığı \%12 olarak bildirilmiştir [6]. B.henselae IgG seropozitifliği evcil hayvan (kedi/köpek) sahiplerinde \%26,5 oranında bulunmuştur [7]. Büyük hastalık veri 
tabanlarında yapılan analizlerde hastalığın yarısından fazlasının 18 yaş altındaki kişilerde görüldüğü bildirilmiştir [8]. Bizim hastamızda da evde kedi besleme ve yakın temas hikayesi vardı.

Bartonella henselae başlangıçta inokülasyon yerinde endotel hücrelerine yerleşir, akut enflamasyona yol açar ve pro inflamatuvar kaskadı aktive eder, 3 ila 10 gün içinde papüler lezyon görülür. 1-2 hafta içinde soliter ya da bölgesel lenf nodu hiperplazisi olur. Genellikle 2-4 haftada kendiliğinden düzelir [9]. Hastamızda primer enflamasyon yeri muayenemizde tespit edilmemekle birlikte, ailesi tarafından da öyküde belirtilmedi.

İmmün sistemi yetersiz olan hastalarda ciddi sistemik hastalık ve diğer atipik bulgular gelişebilir. Bunlar oküloglandülar sendrom, ensefalit, nöroretinit, pnömoni, osteomiyelit, hepatosplenomegali, eritema marginatum, eritema nodozum, artralji, artrit ve trombositopenik purpura olarak bildirilmiştir $[2,3]$. Hastamızın yapılan klinik ve radyolojik konsültasyonlarında sistemik tutuluma ait ek bulgu izlenmedi.

Hastalık tanısında kullanılan klasik kriterler, kediyle yakın temas, kedi tarafından ısırıma veya tırmalanma öyküsü, lenf düğümünden alınan örnekte hastalık için tipik kabul edilen patolojik bulgular ve B. henselae'ye karşı gelişen antikorların immünofluoresans yöntemiyle tespit edilmesidir [10]. Tanıda PCR yöntemi de kullanılabilmektedir. Bizim hastamızda da tanı öykü ve B.henselae IgG ve IgM pozitifliği ile konuldu.

Çoğu vaka kendiliğinden düzelir. Bölgesel lenf nodları ağrılı ise ya da sistemik tutulum varsa antibiyotik verilir. Azitromisin, klaritromisin, rifampisin, siprofloksasin, gentamisin ve trimetoprim-sulfametoksazol vakanın durumuna göre tekli ya da kombine olarak tedavide etkin antibiyotikler olarak bildirilmiştir [6, 11]. Vakamızda önce amoksisilin verilip klinik yanıt alınamaması bizeKTHihtimalinidüşündürmüştü. Biz başlangıç tedavimizde klaritromisin ile trimetoprim-sulfametoksazol'ü birlikte vermiştik. Hastanın şikayetlerinin azalması ve ateşinin düşmesine rağmen lenfadenopati büyüklüğü azalmadığı için azitromisin de verdik.

Kedilerle temastan sonra eller yıkanmalı, tırmık ya da ısırık olan yerler yıkanmalıdır. Ayrıca taşıyıcı vektör olduğundan pirelerle mücadele edilmelidir. Kedilerden bulaşan diğer bakteriyel ve parazit enfeksiyonlarından (zoonoz) korunmak için sık el yıkama, bahçede çalışırken eldiven kullanma ve evcil kedileri düzenli veteriner takibine götürme önerilmektedir [12].

Sonuç olarak, çocuk sağlığı ve hastalıkları polikliniklerinde sık karşıllaşılan lenfadenopatili hastalarda, KTH'nın da ayırıcı tanıda düşünülmesi, önem taşımaktadır. Böyle olgularda, öncelikle KTH'na yönelik spesifik incelemelerin öne alınması, gereksiz tetkiklerin yapılmasını önleyecek ve uygun tedaviye bir an önce başlanmasını sağlayacaktır.

Çıkar ilişkisi: Yazarlar çıkar ilişkisi olmadığını beyan eder.

\section{Kaynaklar}

1. Bergmans AM, Groothedde JW, Schellekens JF, van Embden JD, Ossewaarde JM, Schouls, ML. Etiology of cat scratch disease: comparison of polymerase chain reaction detection of bartonella (formerly rochalimaea) and afipia felis DNA with serology and skin tests. J Infect Dis 1995;171:916-923. https://doi.org/10.1093/ infdis/171.4.916

2. Carithers HA. Cat scratch disease: an overview based on a study of 1,200 patients. Am J Dis Child 1985;139:1124-1133. https://doi.org/10.1001/ archpedi.1985.02140130062031

3. Margileth AM, Wear DJ, English CK. Systemic cat scratch disease: report of 23 patients with prolonged or recurrent severe bacterial infection. J Infect Dis 1987;155:390-402. https://doi.org/10.1093/ infdis/155.3.390

4. Chung JY, Han TH, Kim BN, Yoo YS, Lim SJ. Detection of bartonella henselae DNA by polymerase chain reaction in a patient with cat scratch disease: a case report. J Korean Med Sci 2005;20:888-891. https://doi. org/10.3346/jkms.2005.20.5.888

5. Chomel BB, Kasten RW, Floyd Hawkins K, et al. Experimental transmission of bartonella henselae by the cat flea. J Clinical Microbiol 1996;34:1952-1956.

6. Erinç SM. Investigation of bartonella henselae and bartonella clarridgeiae prevalance in cats. Aydın, Turkey: Adnan Menderes Üniversitesi, Sağlık Bilim Enstitüsü 2015.

7. Aydın N, Korkmazgil B, Kırkan Ş, et al. Seropositivity of bartonella henselae in risky human population, cats and dogs. Meandros Med Dent J 2019;20:51. https:// doi.org/10.4274/meandros.galenos.2018.85057 
8. Jackson LA, Perkins BA, Wenger JD. Cat scratch disease in the united states: an analysis of three national databases. Am J Public Health 1993;83:17071711. https://doi.org/10.2105/ajph.83.12.1707

9. Florin TA, Zaoutis TE, Zaoutis LB. Beyond cat scratch disease: widening spectrum of bartonella henselae infection. Pediatrics 2008;121:1413-1425. https://doi. org/10.1542/peds.2007-1897

10. Gai M, d'Onofrio G, di Vico MC, et al. Cat-scratch disease: case report and review of the literature. Transplant Proc 2015;47:2245-2247. https://doi. org/10.1016/j.transproceed.2015.07.014

11. Margileth AM. Antibiotic therapy for cat-scratch disease: clinical study of therapeutic outcome in 268 patients and a review of the literature. Pediatr Infect Dis J 1992;11:474-478.

12. Kravetz JD, Federman DG. Cat-associated zoonoses. Arch Int Med 2002;162:1945-1952. https://doi. org/10.1001/archinte.162.17.1945

Hasta onamı: Aileden klinik bilgiler ve resimlerin kullanımı için hastadan yazılı onay alınmıştır.

\section{Yazarların makaleye olan katkıları}

G.A. Vakaya son tanıyı koyan, tedavisini planlayan, yazının taslağını ve kaynakçasını hazırlayan, çocuk sağlığı ve hastalıkları uzmanıdır. H.T. Vakayı ilk kabul edip kliniğimize gönderen, yazım sonrası gözden geçiren, çocuk sağlığı ve hastalıkları uzmanıdır. 